Works of the Faculty of Forestry

University of Sarajevo

No 1, 1999 (33-60)

\title{
METODIKA PREMJERA I REGISTROVANJA PODATAKA U JEDNODOBNIM ŠUMSKIM ZASADIMA SMRČE (PICEA ABIES KARST.), BIJELOG BORA (PINES SYLVESTRISL.) I CRNOG BORA (PINUS NIGRA ARN.) U BOSNI I HERCEGOVINI ${ }^{1}$
}

Methodology of measurement and registration of data in even-aged stands of spruce (Picea abies Karst.), Scots pine (Pinus sy/vestris L.) and austrian pine (Pinus nigra) in Bosnia-Herzegovina

\author{
Pavlič Janez \\ Šumarski fakultet Sarajevo
}

Abstract

This paper is dealing with selection and establishment of temporary experimental plots (sample units) in even-aged stands of spruce (Picea abies Karst.), Scots pine (Pinus sy/vestris L.) and austrian pine (Pinus nigra Am.) in Bosnia-Herzegovina for collecting data necessary for the forest management. Data that should be collected on the plots are listed and the way of their measurement is described in detail.

Key words: austrian pine, even-aged stands, sample unit, Scots pine, spruce, taxacional data

\section{Uvod}

Na državnom neobraslom šumskom zemljištu Bosne i Hercegovine postoje mnogi jednodobni šumski zasadi - kulture smrče, bijelog i crnog bora razne starosti. Njihova površina još nije tačno utrvđena, ali se vjeruje da ih je u 1985. godini bilo oko 150.000 ha. Najzastupljeniji zasadi bili su mlađi od 45 godina, ali je bilo i zasada starih 50 i više godina, iz kojih se mogla dobiti izvjesna količina drvne mase za mehaničku preradu. Kolika je zaliha, kvalitet i stmktura drvne mase proizvedene u ovim zasadima značajno je pitanje za buduće gospodarenje ovim šumama.

Uporište za gazdovanje jednodobnim šumskim sastojinama neke vrste drveća pri određenim proredama su prirasno-prinosne tablice. Takve tablice za navedene vrste drveća ne postoje za područje Bosne i Hercegovine, kao ni za pojedine republike bivše Jugoslavije,. Korištenje njemačkih prinosnih tablica (Schober, 1975) za smrču i bijeli bor ili austrijskih (Frauendorfer, 1954) za crni bor, nije bilo korektno jer se radilo o različitim stanišnim uslovima, pogotovo što u Bosni i Hercegovini u ovim sastojinama nisu provođene ma koje mjere njege, pa ni prorede.

${ }^{1}$ Ova istraživanja su dio makroprojekta (Društveni cilj VII): "Korištenje multifunkcionalnih vrijednosti šumskih ekosistema i čuvanje njihove stabilnosti" koji su finansirali Republika Bosna i Hercegovina i šumarska privreda 


\section{Pavlič Janez}

Strane, klasične, prinosne tablice ne sadrže podatke o debljinskoj strukturi zapremine glavne sastojine i prorednog materijala u pojedinim starostima, kao ni podatke o kvalitetnoj strukturi drveta. Ovi podaci su neophodni za procjenu asortimana šumskih proizvoda koji bi se iz zapremine sastojine i zapremine prorednog materijala mogao izraditi u pojedinim starostima. Zbog toga se u Bosni i Hercegovini pristupilo vlastitim istraživanjima razvojnih, strukturnih i proizvodnih karakteristika postojećih jednodobnih šumskih zasada smrče, bjelog i crnog bora. Istaživanja su bila povjerena Katedri za uređivanje šuma Šumarskog fakulteta u Sarajevu i trebalo je da se prva faza istraživanja (izrada metodike rada i terenski radovi) završe za 5 godina. Pošto se klasični metodi istraživanja rasta i prinosa jednodobnih šumskih sastojina provode na stalnim oglednim plohama, i pošto traju koliko i produkcioni period (Matić, 1980), klasični metod istraživanja nije mogao biti primjenjen. Zbog toga je odabran rnetod privremenih oglednih ploha u sastojinama različitih starosti (od najmlađih do najstarijih), na kojima se vrši samo jedan premjer u vrlo kratkom roku. Odgovarajućim povezivanjem podataka došlo bi se do uticaja starosti kao osnovnog faktora pri istraživanju rasta jednodobnih sastojina. U vezi s tim izrađena je, aprila 1986, metodika načina prikupljanja onih podataka i infonnacija za koje je ocjenjeno da su neophodni za utvrđivanje razvojnih, strukturnih i proizvodnih karakteristika jednodobnih šumskih zasada. Ovaj rnetod istraživanja razlikuje od klasičnog i nije do sada objavljivan.

Na osnovu naučne građe prikupljene po ovoj metodici mogle bi se izraditi tablice taksacionih elemenata sastojina koje bi bile prirasno-prinosne tablice za nenjegovane jednodobne sastojine ove tri vrste drveća.

U periodu 1986-1990. godine prikupljeni su, prema priloženoj metodici, podaci u zasađima bijelog bora na 88 ploha, smrče na 72 plohe, te crnog bora u Hercegovini na 90 i Bosni na 156 ploha. Dio ovih istraživanja (proizvodne i strukturne karakteristike jednodobnih sastojina crnog bora u Hercegovini) je saopštio Maunaga Z. 1989., u magistarskom radu odbranjenom na Šumarskom fakultetu u Sarajevu.

U izradi metodike učestvovali su članovi stručnog tima: Stojanović dr Ostoja, Koprivica dr Miloš, Prolić dr Nihad i Maunaga Zoran, kojima se toplo zahvaljujem.

\section{METODIKA}

\subsection{Izbor sastojina za postavljanje privremenih oglednih površina}

Sastojine u kojima se postavljaju ogledne površine određuju rukovodioci terenskih sekcija , nastojeći da što potpunije obezbjede predviđenu strukturu uzorka prema starosti i bonitetu staništa sastojine za svaku istraživanu vrstu drveća unutar centralne, istočne i zapadne Bosne i istočne i zapadne Hercegovine. Na bazi raspoloživih podataka o lokacijima, starosti, srednjoj visini i srednjem prečniku sastojine, prije odlaska sekcije na teren, utvrđuje se za svaku sastojinu postojeća struktura, po

2 Jedna terenska sekcija ima 5 stručnjaka, uključujući i rukovodioca koji organizuje i prati njen rad. Podatke na jednoj plohi prikupljaju dva člana sekcije koji lično obavljaju sva mjerenja. 
Methodology of measurement and registration of data in even-aged stands of spruce ...

navedenim osnovnim obilježjima za svaku geografsku oblast. Zatim se sastavlja orjentacioni spisak i vrši preliminarna registracija lokaliteta za ogledne površine kako bi se obezbijedila predviđena struktura uzorka po starosti sastojina i bonitetu staništa prema visinama. Po odlasku na teren rukovodioci sekcija obilaze registrovane sastojine, prikupljaju dopunske informacije i. imajući u vidu i ostala obilježja, određuju sastojine u kojima će se postaviti ogledne plohe. U okviru tog posla rukovodioci sekcija mogu izabrati sastojine koje se nisu nalazile na spisku, ukoliko nadopunjuju strukturu uzorka prema predviđenim obilježjima. Za postavljanje oglednih površina u obzir dolaze isključivo čiste, prvenstveno vještački osnovane, jednodobne $\mathrm{i}$, po pravilu, neprorjeđivane sastojine, starosti 10 i više godina. Izuzetno, pojedine plohe mogu se postaviti i u djelovima sastojina sa primjesom drugih vrsta drveća do $10 \%$ po broju stabala.

\subsection{Postavljanje ogledne površine i obilježavanje njenih granica}

U svakoj odabranoj sastojim postavlja se, na mjestu koje odredi šef sekcije, po jedna kružna privremena ogledna ploha. Taj dio sastojine treba da je po svojim taksacionim i pedološkim karakteristikama, ekspoziciji i nagibu terena, homogen. U sastojinama starijim od 45 godina i veće površine, mogu se iznimno, radi obezbjeđenja predviđene strukture uzorka, postaviti dvije ili više oglednih površina. Centar ogledne površine označava se stabilnom oznakom na koju se upiše broj plohe. Starost stabala na oglednoj plohi treba da bude približno ista, odnosno da razlika u starosti najmlađeg i najstarijeg stabla ne smije biiti veća od 5 godina. Veličina ogledne plohe zavisi od starosti sastojine i iznosi:

$\begin{array}{ccc}\begin{array}{c}\text { Starost sastojine } \\ \text { (godina) }\end{array} & \begin{array}{c}\text { Površina plohe } \\ \left(\mathrm{m}^{2}\right)\end{array} & \begin{array}{c}\text { Poluprečnik plohe } \\ (\mathrm{m})\end{array} \\ 10-15 & 50,24 & 4.0 \\ 16-25 & 78.50 & 5.0 \\ 26-35 & 132.66 & 6.5 \\ 36-45 & 176.62 & 7.5 \\ 46-55 & 283.38 & 9.5 \\ 56-65 & 346.18 & 10.5 \\ 66-75 & 490.62 & 12.5 \\ 76-85 & 660.18 & 14.5 \\ 86-95 & 854.87 & 16.5 \\ 96-105 & 1.017 .36 & 18.0 \\ 106-115 & 1.193 .98 & 19.5 \\ 116-\mathrm{i} \text { više } & 1.384 .14 & 21.0\end{array}$

Iz tabele se vidi da je za utvrđivanje veličine plohe, odnosno njenog poluprečnika "r" potrebno poznavati starost sastojine. Starost sastojine ocjenjuje se pomoću izvrtaka koji se uzimaju iz najmanje dva stabla, različitih prsnih prečnika, za 


\section{Pavlič Janez}

koje je očigledno da će se nalaziti na plohi. Iz tih stabala uzimaju se izvrtci što je moguće bliže zemlji i do "srca". Na izvrtcima se pažljivo izbroje godovi i, u zavisnosti od visine sa koje je izvrtak uzet, doda na utvrđenu starost još nekoliko godina. Tako utvrđena starost može se, radi kontrole, uporediti i sa brojem godova na svježim panjevima (ako ih ima u blizini). Granica plohe se ne obilježava posebnim znacima, već će se granična stabla unutar plohe, na visini oko $1.6 \mathrm{~m}$ od zemlje, kredom obilježavaju. Granična stabla se određuju horizontalnim odmjeravanjem predviđenog radijusa kruga iz obilježenog centra.

\subsection{Prikupljanje opštih i taksacionih podataka}

\section{2,31 Opšti podaci o stablima ogledne plohe}

Podaci koje treba utvrditi za svaku oglednu plohu navedeni su u obrascima 13 , i treba ih upisati čitko grafitnom olovkom.

OBRAZAC br. 1. Predstavlja omot (korice) manuala, čija se naslovna strana popunjava odgovorima.

OBRAZAC br.2. Namjenjen je za evidentiranje opštih podataka (o organizaciji šumarstva i njenom sjedištu, ŠGP i dr.), zatim orografskih, pedoloških i dijelom taksacionih podataka ogledne plohe kao cjeline.

U predviđene kvadratiće upisuju se šifre koje se naknadno utvrđuju. U prostor predviđen za vrstu drveća upisuju se riječima glavne vrste drveća: smrča, bijeli bor ili crni bor.

U prostor predviđen za starost, upisuje se aritmetička sredina starosti dva posječena stabla na plohi

Nagib terena (okomito na izohipse) mjeri se padomjerom i upisuje u stepenima.

Nadmorska visina procjenjuje se po karti ili se utvrđuje aneroidom.

Ekspozicija plohe se navodi kao: jug, istok, sjevero-zapad itd.

Površina plohe određena je radijusom kruga. Izražava se u ha na 4 decimale.

Stepen sklopa mjeri se duž 4 horizontalne vizure. Na svakoj vizuri registruje se ukupna dužina - pokrivena i nepokrivena krošnjama stabala. Svaka vizura duga je koliko i prečnik plohe i uvijek prolazi kroz centar kruga. Evidentira se prekrivenost vizure (pantljike) krošnjama stabala svih vrsta drveća sa prsnim prečnikom iznad taksacionog praga, odnosno krošnjama obrojčenih stabala. U starijim sastojinama sa podmlatkom u donjoj etaži, sklop se određuje samo na bazi stabala čija starost odgovara onoj na osnovu koje je određen radijus kruga (obrojčena stabla) bez obzira na veličinu prsnog prečnika stabala podmlatka (stabla podmlatka se ne obrojčavaju). Prva vizura za mjerenje sklopa ide u pravcu sjever-jug, druga istok-zapad, a treća i četvrta idu između njih. Zbir prekrivenih i nepokrivenih dijelova svake vizure mora biti jednak dužini prečnika kruga. Stepen sklopa računa se dijeljenjem sume prekrivenih dijelova sve četiri vizure sa ukupnom dužinom svih vizura. 
Methodology of measurement and registration of data in even-aged stands of spruce ...

Obrast sastojine se ne računa na terenu.

Način osnivanja sastojine upisuje se šifrom.

Prirodno, šifra je 1

Vještački, šifra je 2

Sjetvom, šifra je 1

Sadnjom, šifra je2

Uočene karakteristike na plohi opisuju se davanjem odgovora na pitanja postavljena u obrascu. Odgovori na pojedina pitanja treba da pruže informacije o sljedećim podacima:

Prorede. Jesu ili nisu vršene. Ako su vršene treba zapisati broj panjeva nađen na površini plohe i uz to zapisati da li su oni svježi ili stari.

Supstrat. Vrsta, da li izbija na površinu, u kom je obliku i javlja li se mjestimično ili u krpama. Koliko procenata površine plohe zauzimna supstrat koji je izbio na površinu.

Zemljište. Tip i dubina u cm, ako se kopa profil. Ako se profil ne kopa onda se dubina zemljišpa iskazuje opisno po sljedećoj skali:

plitko - dubina do $30 \mathrm{~cm}$, srednje duboko - dubina $30-60 \mathrm{~cm}$

duboko - dublje od $60 \mathrm{~cm}$.

Upisuje se i vrsta humusa i dubina humusnog horizonta $\mathrm{u} \mathrm{cm}$

Oboljenja. Da li su zapažena ili nisu. Ako jesu, treba navesti dio ili djelove stabala na kome se javljaju. Opisati oboljenja i procjeniti broj stabala na kojim su utvrđena i iskazati ih u apsolutnom iznosu ili u procjenjenom procentu (\%) od broja stabala na plohi.

Granatost i čišćenje od grana. Navesti prosječnu udaljenost od zemlje od koje počinju grane većine stabala, bez obzira da li su grane suhe ili žive. Naprimjer, grane počinju od zemlje, ili grane počinju na visini od $1.5 \mathrm{~m}$. Zatim se navodi da li je čišćenje grana (sušenje grana) započelo ili nije. Ako je počelo, navesti visinu na kojoj su grane počele da se suše.

Ponik i podmladak. Ponik čine biljke visine do $10 \mathrm{~cm}$. Da li se javlja na površini plohe. Ako se javlja navesti vrste drveća i način na koji se javlja pojedinačno, u grupama, na oba načina. Da li ga ima po cjeloj površini plohe ili se nalazi u dijelu plohe. Navesti procenat te površine u odnosu na površinu cijele plohe.

Podmladak čine biljke visoke $10-130 \mathrm{~cm}$. Na oglednim plohama u podmladak se svrstavaju i biljke većeg uzrasta ako su mlađe od stabala na osnovu kojih je određen radijus kruga. U tom slučaju podmladak formira svoju etažu i jasno se izdvaja od gornje. Biljke podmlatka više od $130 \mathrm{~cm}$ se evidentiraju na posebnom listu (obrazac br. 3). Ovdje treba opisati i način javljanja podmlatka (pojedinačno, grupno ili kombinovano) i procenat površine (od površine plohe) na kojoj se nalazi. Uz to treba ocijeniti oštećenost podmlatka, vrste oštećenja i procenat oštećenih biljaka u odnosu na broj biljaka podmlatka po vrstama drveća.

Broj godova na nađenim panjevima. Ovaj podatak služi za provjeru starosti utvrđene pri popisu sastojina i za konačno određivanje radijusa plohe. Za tu svrhu uzimaju se samo svježi panjevi sa površine plohe ili, ako ih tu nema, 
iz neoposredne blizine. Dovoljno je izbrojati godove na 2 do 3 panja i zapisati ih u manual. Radijus plohe određuje se nakon provođenja opisane provjere starosti.

Plodonošenje. Ocjenjuje se na bazi pojave šišarica i opisuje riječima.

Na primjer, šišarice se nalaze na pojedinim stablima i ima ih malo. Ili, šišarice se nalaze na oko $30 \%$ stabala u većem broju, a na ostalim stablima in nema. U sastojinama s primjesama drugih četinarskih vrsta drveća, pojava šišarica opisuje se po vrstama drveća. Ukoliko predviđeni prostor nije dovoljan za opis navedenih pojava, opis se daje na poleđini obrasca.

OBRAZAC br. 3. Namjenjen je za upis taksacionih podataka stabala. U taj obrazac upisuju se podaci svakog stabla na oglednoj plohi koje na visini $1.3 \mathrm{~m}$ od tla ima prečnik s korom $0.1 \mathrm{~cm}$ ili više. Na plohama gdje takvih stabala ima u podmladku, i po svojoj starosti ne pripadaju stablima prema kojima je izabran radijus plohe (neobrojčena stabla), popunjavaju se dva lista obrasca 3. Jedan obrazac sa podacima o stablima koja po svojoj starosti pripadaju plohi (obrojčena stabla), a drugi sa podacima o stablima podmladka i donje etaže (neobrojčena stabla). U zaglavlje obrasca za evidentiranje podmlatka krupnim slovima upisuje se riječ podmladak.

Premjer stabala može započeti nakon obilježavanja granica plohe, odnosno, obilježavanja graničnih stabala koja spadaju u plohu. Granična stabala spadaju u plohu ako se uzdužna osovina debla do visine od $1.3 \mathrm{~m}$ nad zemljom nalazi u predviđenom radijusu. Kada se osovina graničnog stabla poklapa s radijusom plohe, u plohu će se svrstavati svako drugo takvo stablo.

Na svako stablo, makar bilo i potpuno suho (sušika), koje po svom prsnom prečniku i starosti dolazi u obzir za premjer i koje spada u plohu, upisuje se na visini iznad $1.6 \mathrm{~m}$ njegov redni broj (šumskom kredom). Na toj visini mrtva kora stabala može se skinuti da bi se broj bolje vidio. Radi preglednosti poželjno je da svi brojevi gledaju na istu stranu. Pojas stabala na visini $1.3 \mathrm{~m}$ od zemljišta mora biti nedirnut do mjerenja prečnika. Stabla koja po svojoj starosti nisu za redovni premjer (donja etaža, podmladak) se ne obilježavaju, osim ako su granična kada se obilježavaju istom oznakom kao i stabla koja se detaljno mjere. Premjer stabala podmlatka sa prsnim prečnikom $0.1 \mathrm{~cm}$ i više vrši se odvojeno od premjera ostalih, tj. obrojčanih stabala.

Redni broj ispisan na stablu upisuje se u kolonu br. 1. obrasca 3.

U kolonu br.2 upisuje se vrsta drveća šifrom:

$\begin{array}{ll}\text { smrča, } & \text { šifra - 1, } \\ \text { bijeli bor, } & \text { šifra - 2, } \\ \text { crni bor, } & \text { šifra - 3, } \\ \text { jela, } & \text { sifra }-4, \\ \text { breza, } & \text { šifra - 5, } \\ \text { trepetljika, } & \text { šifra - 6, } \\ \text { javor, } & \text { sifra - 7, } \\ \text { Sorbus spp. } & \text { šifra - 8, } \\ \text { lipe, } & \text { šifra - 9, } \\ \text { ostali četinari, } & \text { šifra - 10, } \\ \text { ostali liščari, } & \text { šifra - 11. }\end{array}$




\section{Methodology of measurement and registration of dala in even-aged stands of spruce ...}

Svakom obrojčenom stabiu mjere se dva prečnika na visini $1.3 \mathrm{~m}$. Prvi se mjeri s gornje strane i tom prilikom se na stablu linijom obilježi mjesto koje su kraci prečnice dodirivali. Prečnica pri tom mjerenju mora da stoji okomito na uzdužnu osovinu stabla. Drugi prečnik mjeri se okomito na prvi, na visini koju određuju linije nacrtane pri prvom mjerenju. Podaci prvog i drugog mjerenja prečnika upisuju se u 3. i 4. kolonu obrasca. Prečnici se mjere do na milimetar tačnosti. Na primjer, 23,7 i 24,1 cm. Prečnik, kao i veličine ostalih podataka, mjere isključivo članovi sekcije uz najveću pažnju i provjeru.

U kolonu 5 upisuje se aritmetička sredina izmjerenih prečnika zaokruženo na parne milimetre.

U kolonu 6 upisuje se temeljnica srednjeg prečnika stabla u m2 na četiri decimale. U sastojinama sa primjesama drugih vrsta drveća temeljnica se iskazuje samo za glavnu vrstu drveća. Za sušike temeljnica se ne iskazuje.

Nakon premjera prečnika mjere se visine (visinomjerom ili letvom) svih obrojčenih stabala i sušika i dužina debla od zemlje do mjesta gdje započinje krošnja, tj. dužina debla čistog od grana. Podaci se upisuju u kolone u 7 i 8, zaokruženjem na pola metra. Na primjer, 18,$5 ; 6,5 ; 8,0$ itd.

U kolone 9, 10 i 11 upisuju se podaci sa izvrtka, koji se uzimaju samo iz živih stabala sa prsnim prečnikom $5 \mathrm{~cm}$ i više. Stabla se buše na visini $1,3 \mathrm{~m}$, koja je već obilježena pri mjerenju prečnika. Na kosom terenu stabla se buše s gornje strane. Iz svakog stabla uzima se samo jedan izvrtak. Na izvrtku se izmjeri debljina kore s kambijem na puni milimetar i upisuje u kolonu 9. Zatim se na izvrtku odbroji od periferije (od kore) ka centru 10 godova. Ta dužina se izmjeri i na puni milimetar upiše u kolonu 10. Na istom izvrtku odmjeri se od kambija ili periferije posljednjeg potpunog goda ka srcu 25 milimetara i izbroji broj godova koji se na toj dužini nalaze. Taj podatak upisuje se u kolonu 11.

Pri brojanju i premjeru godova ne uzima se u obzir neformiran ovogodišnji god.

U kolonu 12 upisuje se uzgojno-tehnička kvalitetna klasa svih obrojčenih stabala, a u kolonu 13 njihova tehnička klasa prema priloženoj, pojednostavljenoj, klasifikaciji (Matić, 1971) za odgovarajuću vrstu drveća. Klasificiraju se samo stabla sa srednjim prsnim prečnikom $5 \mathrm{~cm}$ i više, dakle samo ona stabla iz kojih je uzet izvrtak, kao i sušike.

U kolone 14. 15. 16. 17, 18, 19 i 20 upisuju se klase stabala na osnovu IUFRO klasifikacije (Pintarić, 1969) koja je dio ove metodike. Ovoj klasifikaciji podliježu sva obrojčena stabla (i sušike), bez obzira na veličinu prsnog prečnika. Za primjenu ove klasifikacije potrebno je poznavati gornju sastojinsku visinu ogledne plohe koja se mora izračunati.

U okviru IUFRO klasifikacije na plohi se najprije vidno obilježe (komadom papira) "odabrana stabla" ako ih ima. Zatim se ide od stabla do stabla i ocjenjuje klasa. Pri procjeni uzgojne uloge pojedinog stabla treba mu odrediti ulogu u odnosu na "odabrana stabla" koja za uzgojnu ulogu dobiju ocjenu 400. Ta ocjena se može dati najboljim stablima, ako se nalaze u gornjoj etaži i ako su dobro raspoređena po površini plohe. Ako se dva kvalitetna stabla nalaze jedno do drugoga i ako jedno od njih 


\section{Pavlič Janez}

smeta razvoju drugog, tada ocjenu 400, odnosno "odabrano" može da bude samo jedno od njih, dok drugo, za uzgojnu ulogu, dobija ocjenu 600. jer ometa razvoj prvog tj. odobranog stabla. Ako se na plohi ne može proglasiti ni jedno stablo odabranim, stabla se klasificiraju po redu, s tim da ni jedno ne može imati za uzgojnu ulogu ocjenu 400.

U kolonu 21, se na terenu ne upisuju podaci. Odnose se na shematsku proredu vezanu za podatke provedene IUFRO klasifikacije stabala na plohi.

U kolonu 22, šifrom se upisuje da li razmatrano stablo treba ukloniti iz sastojine iz šumsko-uzgojnih razloga (šifra 1) ili ne (šifra 0). Stabla koja treba ukloniti pripadaju, po pravilu, trećoj klasi uzgojno-tehničke klasifikacije (Matić,1971), kao što su sušike, prelomljena ili prevršena stabla, zatim oboljela, jače oštećena stabla i stabla koja ometaju razvoj stabala boljeg kvaliteta nego što su ona.

U koloni 23 za uočene greške stabla upisuje se šifre:

\begin{tabular}{lr} 
Četine žute & \multicolumn{1}{c}{ šifra } \\
Suhovrho & 2 \\
Prevršeno & 3 \\
Prelomljeno & 4 \\
Zakrivljeno & 5 \\
Natrulo & 6 \\
Zaguljena kora & 7 \\
Račva & 8 \\
Imela & 9 \\
Rak & 10 \\
Ekstremno razvijena ili nerazvijena krošnja & 11 \\
Zastarčeno & 12 \\
Mišorepo & 13 \\
Nagnuto (skošeno) & 14 \\
Lira & 15 \\
Sušika & 16
\end{tabular}

Ako stablo nema nijednu grešku upisuje se "0" (nula). Uz šifru treba riječima opisati mjesto gdje se greška nalazi. Na primjer: vrh, žilište, donji dio krošnje i si. Uz šifru 11 treba dopisati: uska, široka, bič, jednostrana i si.

Ako se na stablu nalazi više grešaka onda se druga ili ostale upisuju na poleđini obrasca uz predhodno zapisivanje rednog broja tog stabla.

Da bi se znalo da na poleđini obrasca ima podataka, treba pri dnu stranice napisati riječ: okreni.

Na kraju svakog obrasca br. 3 saberu se iskazane temeljnice obrojčenih stabala glavne vrste drveća i to bez temeljnice sušika (one nisu ni iskazane), a na posljednjem obrascu iskazuje se suma temeljnica svih obrojčenih stabala glavne vrste drveća sa te plohe. Dijeljenjem te sume temeljnica sa brojem stabala za koje je iskazana dolazi se do temeljnice srednjeg sastojinskog stabla glavne vrste drveća. Na osnovu nje odredi se srednji prečnik te vrste drveća (ds). Osim tog prečnika treba izračunati i aritmetički srednji prečnik obrojčenih stabala glavne vrste drveća na plohi. On se dobije 


\section{Methodology of measurement ami registration of data in even-aged stands of spruce ...}

dijeljenjem sume prečnika iz kolone 5 sa brojem stabala. U taj zbir ne ulazi prečnik sušika.

Zbrajanjem visina obrojčanih stabala glavne vrste drveća i dijeljenjem sa brojem stabala dolazi se do aritmetički srednje sastojinske visine tih stabala (/?). Pri računanju sume visina premjerenih stabala ne uzimaju se u obzir (u zbir) visine stabala primiješanih vrsta drveća i visine nenormalno formiranih stabala, tj. suhih, prevršenih, prelomljenih, suhovrhih, račvastih i ekstremno nagnutih stabala (podaci o tome nalaze se u koloni 23).

Gornja sastojinska visina računa se na bazi visina živih i normalno formiranih stabala svih vrsta drveća na plohi koja su obrojčena. U tu svrhu najprije se izračuna broj stabala na osnovu kojeg će se računati gornja visina. On iznosi $20 \%$ od broja stabala (svih vrsta drveća) čije visine ne treba odbaciti. Dijeljenjem sume tih visina s brojem uzetih stabala dolazi se do gornje visine $(\mathrm{Hg})$. Ova visina koristi se pri IUFRO klasifikaciji stabala.

Preostalim stablima koja nisu obrojčena, a nalaze se na površini plohe mjere se prsni prečnici i visine, ako su viša od $1.3 \mathrm{~m}$ (stabla podmlatka, odnosno, donje etaže). Ovi podaci i šifre za vrstu drveća upisuju se na posebnom listu obrasca 3. Tim stablima mjeri se samo jedan prečnik i upisuje u kolonu 5. Ostali podaci se ne mjere i ne računaju.

\subsection{Podaci o srednjim sastojinskim stablima plohe}

OBRAZAC br. 4 predviđen je za upisivanje podataka o srednjim sastojinskim stablima. Podaci o srednjim sastojinskim stablima i sortimentima prikupljaju se na svakoj oglednoj plohi. Podaci za analizu stabla prikupljaju se na plohama u Bosni u sastojinama starim 46 ili više godina, a na području Hercegovine u sastojinama starim 20 i više godina.

Podaci o srednjim sastojinskim stablima prikupljaju se za dva stabla glavne vrste drveća koja su po svojim dimenzijama najbliža izračunatoj aritmetički srednjoj visini i debljini srednjeg sastojinskog stabla po temeljnici $h$ i ds. Redni brojevi tih stabala nalaze se u obrascu 3. Zatim se ta stabla pronađu na plohi i posjeku. Ta stabla moraju biti normalno formirana. Suhovrha, račvasta, suha, bajonet i prevršena stabla ne dolaze u obzir.

U obrazac 4 šifrom se upisuje: u kolonu 1 vrsta drveća, u kolonu 2 izračunati srednji prečnik srednjeg sastojinskog stabla glavne vrste drveća po temeljnici, u kolonu 3 srednji prečnik stabla za koje je ocjenjeno da ima prečnik i visinu najbliže izračunatom (iz obrasca 3).

Prije sječe tih stabala treba provjeriti njihove prečnike i visine i da li su normalno formirana.

U kolonu 4 prepisuju se redni broj tih stabala iz obrasca 3.

Nakon sječe premjere se prečnici na panju sa korom i upišu u kolone 5 i 6 do na milimetar tačnosti. Njihova aritmetička sredina upisuje se u kolonu 7.

U kolonu 8 upisuje se visina panja u metrima na dvije decimale. Na kosom terenu visina panja mjeri se sa gornje strane. 


\section{Pavlič Janez}

U kolonu 9 upisuje se broj godova na panju. Broj godova broji se duž dva najduža poiuprečnika, gdje su godovi najuočljiviji. Rezultat mora biti isti.

Zatim se mjeri dužina debla od prereza na panju do vrha (L) i upisuje u kolonu 10, u metrima na dvije decimale .

U kolonu 11 upisuje se dužina od prereza na panju do mjesta na deblu gdje je sredina unakrsno mjerenih prečnika s korom $7.00 \mathrm{~cm}\left(L_{7}\right)$.

U kolonu 12 upisuje se dužina od prereza na panju do mjesta gdje je sredina unakrsno mjerenih prečnika na deblu s korom $5.00 \mathrm{~cm}\left(\mathrm{~L}_{5}\right)$.

U kolonu 13 upisuje se u gornjoj polovini polja (reda) dužina debla od prereza na panju do mjesta gdje počinje krošnja (dužina debla čistog od grana - $L_{2}$. U donjem redu upisuje se prečnik debla na tom mjestu s korom (sredina iz dva mjerenja do na milimetar tačnosti).

Dužine $L^{7}$ i $L^{5}$; i dužina debla čistog od grana $L^{2}$, mjere se i upisuju u metrima na dvije decimale, na primjer $9,72 \mathrm{~m}$.

Zatim se izračunaju (u metrima na dvije decimale) dužine: $L^{7}$ polovina, $L^{5}$ polovina i dužine $0,1 \mathrm{~L}, 0,3 \mathrm{~L}, 0,5 \mathrm{~L}, 0,7 \mathrm{~L}$ i $0,9 \mathrm{~L}$ i upišu u gornjem redu kolona 14 , $15,16,17,18,19,20$.

Izračunate dužine se, počev od panja, odmjeravaju i označavaju na deblu. Na označenim mjestima izmjere se unakrsno po dva prečnika s korom. Njihove aritmetičke sredine upisuju se u donji red odgovarajućih kolona, zaokružene na parne milimetre.

U kolone 21 do 26 upisuju se podaci 0 granama i to broj sekcija grana dužine $1 \mathrm{~m}$, koje u sredini te dužine imaju prečnik s korom 5 ili više $\mathrm{cm}$.

Broj sekcija grana s prečnikom od $5 \mathrm{~cm}$ upisuje se u gornji red kolone $21 . \mathrm{U}$ donji red upisuje se broj sekcija grana koje u sredini imaju prečnik $s$ korom $6 \mathrm{~cm}$ itd. Pod prečnikom od $5 \mathrm{~cm}$ evidentiraju se prečnici od 5.0 do $5.9 \mathrm{~cm}$, a pod prečnikom od $6 \mathrm{~cm}$ evidentiraju se prečnici od 6.0 do $6.9 \mathrm{~cm}$ itd.

Krojenje sortimenata iz posječenih stabala vrši se na osnovu propisa za standarde (korišteni su propisi Savezne komisije za JUS bivše Jugoslavije) pri tome treba voditi računa da se iskrajaju vrjedniji sortimenti uz racionalno korištenje drveta.

Za svako stablo se na poleđini obrasca br. 4 nacrta skica uzdužnog presjeka stabla i na njoj, idući od prereza na panju, ucrtava, uz stacionažu, svaki iskrojeni sortiment i dio koji se odbacuje, sa ispisivanjem naziva sortimenta i njegove dužine. Ispod skice ispisuju se nazivi iskrojenih sortimenata i uz njih upisuju njihove dimenzije prema propisima JUS-a. Uz skicu se upisuje i broj stabla koji je određen pri obrojčavanju.

Iskrojeni sortimenti se ne izrađuju. Zato pri krojenju treba voditi računa 0 prostoru koji zauzima: prorezivanje, nadmjera i ostale odredbe standarda (JUS-a).

2.33 Dendrometrijska analiza

OBRAZAC br. 5. Predviđen je za upisivanje podatake potrebnih za dendrometrijsku analizu stabala, što se radi nakon krojenja. Izrezani koturovi za dendrometrijsku analizu svakog stabla odlažu se u 


\section{Methodology of measurement and registration of data in even-aged stands of spruce ...}

posebnu vreću i transportuju do sjedišta sekcije gdje se zatim analiziraju.

Dendrometrijska analiza provodiće se u Bosni za plohe stare 46 i više godina, a u Hercegovini za plohe stare 20 i više godina. Za tu svrhu koriste se ista stabla koja su posječena za prethodna mjerenja.

U kolonu br. 1 upisuje se visina prereza. Prvi prerez je na visini panja, drugi mora biti na visini 1,3 m (uzimajući u obzir i visinu panja). Ostali su po pravilu, na rastojanju od po $2 \mathrm{~m}$, sve dok dužina debla omogućava krojenje sekcija navedene dužine $(2 \mathrm{~m})$. Sa tih visina isjecaju se koturi debljine oko $2 \mathrm{~cm}$. Gornja strana kotura mora se nalaziti na označenoj visini prereza. Ako se mjesto prereza, odnosno uzimanje kotura mora pomjeriti, zbog pršljena grana ili drugog razloga, do $10 \mathrm{~cm}$ na jednu ili drugu stranu, onda se u obrascu zadržava, naznačena visina prereza. Međutim, kada se prerez mora pomjeriti više od $10 \mathrm{~cm}$, u obrazac se upisujue dužina sa koje je kotur stvarno uzet.

Dalji rad na prikupljanju podataka za analizu stabala sastoji se u sljedećem:

Na svakom koturu nacrtaju se dva međusobno okomita prečnika i duž njihovih poluprečnika izbroji broj godova (od periferije do srca). Rezultat, koji mora biti isti, upisuju se u kolonu 2.

Polazne tačke ovih prečnika treba na svakom koturu da polaze od istih strana debla. To se postiže stavljanjem oznaka na kori koturova prije nego što se isjeku iz debla. Ove oznake treba da se nalaze na gornjoj strani debla (suprotno od strane na kojoj leži) jer je najpristupačnija. Na koturu se po odsjecanju ispisuje visina sa koje je uzet. Zatim se na svakom koturu obilježavaju periodi od po 10 godina i to tako da odgovaraju starosti stabla u 10., 20., 30., 40. itd. godini. Pri formiranju tih perioda mora se uzeti u obzir sadašnja starost stabla. U Hercegovini će za stabla starosti 20 do 46 godina ti periodi obuhvatiti 5 godina, s tim da odgovaraju starostima od 5, 10, 15 itd. godina (kod starijih stabala periodi su 10-godišnji).

OBRAZAC br. 6. Namjenjen je za visinsku analizu stabla.

$\mathrm{U}$ alineju 1 upisuju se visine na deblu na kojim su isječeni koturovi za dendrometrijsku analizu zaokružene na decimetar.

$\mathrm{U}$ alineju 2 upisuje se broj godova koturova isječenih na naznačenim visinama debla. Na vrhu svakog debla broj godova 0 (nula).

Za alineju 3 podaci se računaju oduzimanjem broja godova utvrđenih na isječenim koturovima (alineja 2) od utvrđene starosti stabla koja se upisuje u zaglavlju ove tabele.

U alineju 4 upisuje se broj godova izbrojan na susjednom nižem i višem koturu. Razlika u broju godova je broj godina koji je bio potreban stablu da naraste u visinu od jednog do narednog presjeka (kotura).

$\mathrm{U}$ alineju 5 upisuje se izračunati godišnji visinski prirast (prosječni periodični) u svakom od vremenskih perioda koji su utvrđeni u prethodnoj alineji. Godišnji visinski prirast utvrđuje se dijelenjem razlike visine analiziranog i nižeg susjednog presjeka sa razlikom broja godova na tim presjecima. Godišnji visinski prirast računa se na tri decimale.

Alineja 6 podijeljena je u tri reda. $U$ gornji red upisuju se starosti za koje se 


\section{Pavlič Janez}

želi znati visina i dužina ovrška. U zasadima starosti $20-46$ godina visine se izračunavaju za 5-godišnje periode $(5,10,15$....godina), a u starijim za 10-godišnje periode $(10,20,30$....godina). $\mathrm{U}$ srednji red upisuju se visine analiziranog stabla u starosti navedenoj u prethodnom redu. Pri utvrđivanju visine stabla u željenoj starosti očita se iz alineje 3 ovog obrasca broj godina koji je bio potreban stablu da naraste do najbliže manje visine presjeka iz alineje 1 . Na očitanu visinu dodaje se iz naredne kolone alineje 5 visinski prirast za broj godina koji nedostaje do željene starosti stabla. U treći red upisuje se dužina ovrška stabla u iskazanoj starosti (iz prvog reda ove alineje). Ovršak predstavlja razliku između utvrđene visine stabla u nekoj starosti i visine najbližeg nižeg presjeka stabla koja je iskazana u alineji 1.

\section{Zaključak}

Prikazana je detaljna metodika izbora čistih jednodobnih, pretežno vještački osnovanih, zasada smrče (Picea abies Karst.), bijelog bora (Pimis sy/vestris L.) i crnog bora (Pinus nigra Am.), načina postavljanja oglednih ploha, te prikupljanja opštih i taksacionih podataka stabala na oglednim plohama i za njihova srednja sastojinska stabla. Uz to su izložene primjenjene klasifikacije stabala.

Metodika treba da služi za prikupljanje građe za utvrđivanje razvojnih, strukturnih i proizvodnih karakteristika jednodobnih čistih zasada navedenih vrsta drveća u Bosni i Hercegovini. Razlikuje se od klasične metode koja podrazumijeva stalne ogledne površine i periodična kontinuelna opažanja u toku produkcionog perioda uobičajenog za određenu vrstu drveća. Međutim, za brza istraživanja razvoja, prirasta i prinosa čistih jednodobnih šuma, klasičan metod nije pogodan.

\section{Literatura}

1. Frauendorfer, R. (1954): Forstliche Hilfstafeln. Wien.

2. Matić V. et al (1971): Stanje šuma u SR Bosni i Hercegovini prema inventuri šuma na velikim površinama u 1964-1968. g. Šumarski fakultet i Institut za šumarstvo u Sarajevu. Posebno izdanje br. 7.

3. Matić V. (1980): Prirast i prinos šuma.Udžbenik. Univerzitet u Sarajevu

4. Maunaga. Z (1989): Proizvodne i strukturne karakteristike jednodobnih sastojina crnog bora (Pinus nigra Am.) u Hercegovini. Magistarski rad. Šumarski fakultet. Univerziteta u Sarajevu

5. Mirković D. (1954): Dendrometrija. Udžbenik: Univerzitet u Beogradu. Naučna knjiga, Beograd.

6. Pintarić K. (1969): Njega šuma. Udžbenik. Univerzitet u Sarajevu .

7. *** Savezna komisija za standardizaciju (JUS-Jugoslovenski standard za oblast šumarstva), Beograd. Obnove:D.BO.020, januar 1969.-gradnja drveta, D. BO. 021, januar 1969.greške drveta, D.BO. 022, januar 1969.-razvrstavanje i mjerenje, D. BI. 022. okto bar 1968,-šipovi, D.B1.023, oktobar 1968.-mdničko drvo, D.B2.022, april 1968.TT stubovi, D.B3.020-stubovi za hmelj i vinograde i kolje, D.B3.022. decembar 1964 motke. D.B4.021 septembar 1968. - furnir, D.B4.029 septembar 1968,-pilans ki trupci, D.B4.039 septembar 1968.- pilanski trupci, D. B5 020 maj 1966.- celuloza, 
Methodology of measurement and registration of data in even-aged stands of spruce ...

i D.B5 023. oktobar 1968.- ogrevno drvo.

8. Schober R. (1975): Ertragstafeln wichitiger Baumarten.J.D. Sauerlaenders Verlag, Frankfurt am Main.

\section{Summary}

The methods described here are related to (i) selection of the pure even-aged, mostly men-made, stands of spruce (Picea a ties Karst.), Scots pine (Pimts sy/vestris L.) and austrian pine (Pimts nigra Am.) that are suitable for establishment of the temporary experimental plots, and (ii) collection of general and taxacional data at these plots which may be relevant to forest management with such a type of forests. These methods should replace the classical method based on collecting data on permanent plots throughout the production period thus being inconvenient for a quick collection of relevant data. It is expected the methods to be of useful to experts who are interesting in further growth, structural and productive development of these type of conifer stands in Bosnia-Herzegovina. The tree classification that are used in these methods are presented in the annex.

\section{PRILOZI - APPENDIX}

(klasifikacije stabala, komplet obrazaca br 1, 2, 3, 4, 5 i 6) I. UZGOJNO-TEHNIČKA KLASIFIKACIJA STABALA SMRČE, BIJELOG I CRNOG BORA PREMA MATIĆ V. et al.(1971) - MODIFICIRANA VERZIJA

U okviru uzgojno-tehničke klasifikacije stabala formirane su tri klase i to: I, II, i III. Za prvu i treću klasu uslovi su definisani. U drugu klasu svrstavaju se sva ostala stabla koja se ne mogu svrstati u prvu ili treću.

Unutar klase I i III uslovi su razrađeni posebno za stabla prsnog prečnika 50 $\mathrm{cm}$ i više, za stabla između 30 i $50 \mathrm{~cm}$ prsnog prečnika, stabla debljine $10-30 \mathrm{~cm}$ i za stabla $5-10 \mathrm{~cm}$ prsnog prečnika.

Pri ovoj klasifikaciji uzimaju se u razmatranje sljedeće osobine stabala: zdravstveno stanje i izgled stabla, izgled četina, nadžilje, deblo, račva, zakrivljenost debla, ozlijeđenost debla, grane, imela i vilina metla, položaj u odnosu na diuga stabla, zastarčenost, prevršenost i prelomijenost stabala, suhovrhost i pojava raka.

U prvu klasu se u principu svrstavaju ona stabla koja se mogu uzgojiti ako se u sastojini sistematski provode mjere njege, tj. kvalitetna, zdrava i normalno formirana stabla. U treću se klasu svrstavaju u načelu ona stabla koja u privrednoj šumi ne bi smjela da se nalaze (trula, jako ozlijeđena, prelomljena i ona zdrava stabla iz kojih se, zbog grešaka na deblu, može izrađivati jedino cijepano drvo). U drugu uzgojno-tehničku klasu svrstavaju se ostala stabla sastojine. 
Pavlič Janez

\subsection{UZGOJNO-TEHNIČKA KLASIFIKACIJA STABALA SMRČE PRSNOG PREČNIKA $50 \mathrm{~cm}$ I VIŠE S KOROM}

\begin{tabular}{|c|c|c|}
\hline $\begin{array}{c}\text { Elementi koji se } \\
\text { ocjenjuju }\end{array}$ & Prva klasa & Treća klasa \\
\hline 1 & 2 & 3 \\
\hline $\begin{array}{l}\text { Zdravstveno stanje i } \\
\text { izgled stabla }\end{array}$ & Zdravo i normalno formirano & $\begin{array}{l}\text { Loše formirano, a zdravo, jako } \\
\text { ozlijedeno, natrulo ili bolesno }\end{array}$ \\
\hline Cetine & Zdrave, zelene & Blijede, prorjedene \\
\hline Nadžilje & $\begin{array}{l}\text { Deformisano do } 1,5 \mathrm{~m} \\
\text { Zdravo }\end{array}$ & Natrulo \\
\hline Deblo & $\begin{array}{l}\text { Zdravo, pravno, čisto i punodrvno iznad } \\
\text { nadžilja u dužini najmanje do trećine visine } \\
\text { stabla, tj. H/3. Na tom dijelu od H/3 dopuštaju } \\
\text { se istovremeno sljedeće greške: u donjoj } \\
\text { trećini po koji čaprljak grana debljine do } 2 \mathrm{~cm} \text {. } \\
\mathrm{U} \text { gornje dvije trećine čaprljci i suhe grane do } \\
2 \mathrm{~cm} \text { debljine i žive grane debljine do } 3 \mathrm{~cm} \text {. U } \\
\text { gornjoj trečini pršljenovi živih grana debljine } \\
\text { do } 6 \mathrm{~cm} \text { i to po jedan pršljen po tekućem } \\
\text { metru. }\end{array}$ & $\begin{array}{l}\text { Svako natrulo i ono stablo iz čije se } \\
\text { donje H/3 ne moźe izdvojiti ni dio } \\
\text { debla dužine } 3 \text { m sa jednom od } \\
\text { sljedećih grešaka; tri grane po } \\
\text { tekućem metru debljine do } 10 \mathrm{~cm} \text {, } \\
\text { zakrivljenost debla do } 3 \% \text { visine } \\
\text { luka, usukanost po tekućem metru do } \\
25 \% \text { prečnika, ili istovremeno sve } \\
\text { navedene greške. }\end{array}$ \\
\hline Rašlja (račva) & $\begin{array}{l}\text { Svrstava se u prvu klasu ako se rašlja nalazi u } \\
\text { gornjoj } \mathrm{H} / 2 \text {, a zadovoljava predhodno }\end{array}$ & $\begin{array}{l}\text { Ako su predhodni uslovi takvi } \\
\text { svrstava se u III klasu bez obzira na } \\
\text { rašlje }\end{array}$ \\
\hline Ozljede debla & Dozvoljena do $5 \mathrm{~cm}$ širine & Sira od $10 \mathrm{~cm}$ \\
\hline Izlomljene i suhe grane & $\begin{array}{l}\text { Dozvoljene u gornjoj } 2 / 3 \text { krošnje s tim da } \\
\text { njihov broj nije veći od } 1 / 10 \text { svih živih grana u } \\
\text { tom dijelu krošnje }\end{array}$ & Neograničeno \\
\hline Imela ili vilina metla & Dopušteno do na $1 / 10$ svih grana & Neograničeno \\
\hline Nadvišeno & $\mathrm{Ne}$ & $\mathrm{Da}$ \\
\hline Zastarčeno & $\mathrm{Ne}$ & $\mathrm{Da}$ \\
\hline Prevršeno & $\mathrm{Ne}$ & $\begin{array}{l}\text { Više od } 1 / 10 \text { dužine krošnje ili više } \\
\text { od } \mathrm{H} / 20\end{array}$ \\
\hline Prelomljeno & $\mathrm{Ne}$ & Svako \\
\hline Suhovrho & $\mathrm{Ne}$ & $\begin{array}{l}\text { Više od } 1 / 10 \text { dužine krošnje ili više } \\
\text { od } \mathrm{H} / 20\end{array}$ \\
\hline Rak & $\mathrm{Ne}$ & $\begin{array}{l}\text { Zdrav ako je zahvatio više od } \mathrm{H} / 2 \mathrm{i} \\
\text { svaki bolestan }\end{array}$ \\
\hline
\end{tabular}

\subsection{UZGOJNO-TEHNIČKA KLASIFIKACIJA STABALA SMRČE PRSNOG PREČNIKA 30-50 cm S KOROM}

\begin{tabular}{|c|c|c|}
\hline $\begin{array}{l}\text { Elementi koji se } \\
\text { ocjenjuju }\end{array}$ & Prva klasa & Treća klasa \\
\hline 1 & 2 & 3 \\
\hline $\begin{array}{l}\text { Zdravstveno stanje i } \\
\text { izgled stabla }\end{array}$ & Zdravo i normalno formirano & $\begin{array}{l}\text { Loše zdravo stablo, jako ozlijedeno, natrulo, } \\
\text { trulo ili bolesno }\end{array}$ \\
\hline Cetine & Zdrave, zelene & Blijede i prorjedene \\
\hline Nadžilje & Deformisano do visine $1 \mathrm{~m}$, zdravo & Natrulo i trulo bez obzira na deformisanost \\
\hline Deblo & Kao za stablo $50 \mathrm{~cm}$ i više. & Kao za stablo $50 \mathrm{~cm}$ i više. \\
\hline Rašlja (račva) & $\begin{array}{l}\text { Dopuštena u gornjoj } \mathrm{H} / 3 \text { (u gornjoj } \\
\text { trećini visine) }\end{array}$ & $\begin{array}{l}\text { Nije bitno ako postoji neki od predhodnih } \\
\text { uslova }\end{array}$ \\
\hline Zakrivljenost & U gomjoj trećini visine stabla dopuštena & Nije bitno \\
\hline Ozljede debla & Dozvoljena do širine $5 \mathrm{~cm}$ & Sira od $10 \mathrm{~cm}$ \\
\hline Izlomljene i suhe grane & $\begin{array}{l}\text { Dopušteno samo dvije grane u gornje } 2 / 3 \\
\text { krošnje }\end{array}$ & Neograničeno \\
\hline Imela ili vilina metla & Dopušteno samo na dvije grane & Neograničeno \\
\hline Nadvišeno & $\mathrm{Ne}$ & $\mathrm{Da}$ \\
\hline Zastarčeno & $\mathrm{Ne}$ & $\mathrm{Da}$ \\
\hline Prevršeno & $\mathrm{Ne}$ & Više od $1 / 10$ dužine krošnje ili više od $\mathrm{H} / 20$ \\
\hline Prelomljeno & $\mathrm{Ne}$ & Svako \\
\hline Suhoviho & $\mathrm{Ne}$ & Svako \\
\hline Rak & $\mathrm{Ne}$ & Svako \\
\hline
\end{tabular}




\subsection{UZGOJNO-TEHNIČKA KLASIFIKACIJA STABALA SMRČE PRSNOG PREČNIKA 10-30 cm S KOROM}

\begin{tabular}{|c|c|c|}
\hline $\begin{array}{l}\text { Elementi koji se } \\
\text { ocjenjuju }\end{array}$ & Prva klasa & Treća klasa \\
\hline 1 & 2 & 3 \\
\hline $\begin{array}{l}\text { Zdravstveno stanje i } \\
\text { izgled stabla }\end{array}$ & Zdravo i normalno formirano & $\begin{array}{l}\text { Loše zdravo, jako ozlijedeno, natrulo, } \\
\text { trulo ili bolesno }\end{array}$ \\
\hline Cetine & Zdrave i zelene & Blijede ili prorjedene \\
\hline Nadžilje & Bez deformacija & Deformiasno više od $1 \mathrm{~m}$ \\
\hline Deblo & $\begin{array}{l}\text { Zdravo, pravno i punodrvno u cijeloj visini } \\
\text { stabla. Ako je čišćenje od grana takvo da u } \\
\text { donjoj H/3 nema živih grana i ako postoje } \\
\text { izgledi da će se nastaviti taj proces s } \\
\text { obzirom na položaj stabla }\end{array}$ & $\begin{array}{l}\text { Natrulo, oboljelo, trulo i ono koje ime } \\
\text { neke od sljedećih nedostataka: čiśćenje u } \\
\text { donjoj H/3 nije započelo i nema izgleda } \\
\text { da će se nastaviti tj. započeti u narednih } \\
10 \text { godina. Usukanost po tekućem metru } \\
\text { veću od } 10 \% \text { D. Zakrivljenost } 2 \% \\
\text { visine luka i više. Višestruko zakrivljeno. }\end{array}$ \\
\hline Rašlje & $\mathrm{Ne}$ & $\mathrm{Da}$ \\
\hline $\begin{array}{l}\text { Zakrivljenost i ozljede } \\
\text { debla }\end{array}$ & $\mathrm{Ne}$ & Neograničeno \\
\hline Izlomljene i suhe grane & $\mathrm{Ne}$ & $\mathrm{Da}$ \\
\hline Imela ili vilina metla & $\mathrm{Ne}$ & $\mathrm{Da}$ \\
\hline Nadvišeno & Ne od boljih stabala & Da od boljih stabala \\
\hline Zastarčeno & $\mathrm{Ne}$ & Svako \\
\hline Prevršeno & $\mathrm{Ne}$ & Da \\
\hline Prelomljeno & $\mathrm{Ne}$ & Svako \\
\hline Suhovrho & $\mathrm{Ne}$ & Svako \\
\hline Rak & $\mathrm{Ne}$ & Svako \\
\hline
\end{tabular}

\subsection{UZGOJNO TEHNIČKA KLASIFIKACIJA STABALA SMRČE TANJA OD $10 \mathrm{~cm} S$ KOROM}

\begin{tabular}{|l|l|l|}
\hline \multicolumn{1}{|c|}{$\begin{array}{c}\text { Elementi koji se } \\
\text { ocjenjuju }\end{array}$} & \multicolumn{1}{|c|}{ Prva klasa } & \multicolumn{1}{c|}{ Treća klasa } \\
\hline \multicolumn{1}{|c|}{$\begin{array}{l}\text { Zdravstveno stanje i } \\
\text { izgled stabla }\end{array}$} & Zdravo i normalno formirano & $\begin{array}{l}\text { Loše zdravo, jako ozlijedeno, natrulo, } \\
\text { trulo ili bolesno }\end{array}$ \\
\hline Cetine & Zdrave i zelene & Blijede ili prorjeđene \\
\hline Nadžilje & Zdravo i bez deformacija & Natrulo ili deformisano \\
\hline Deblo & $\begin{array}{l}\text { Pravno i punodrvno u cijeloj visini. Č́š́cnje } \\
\text { je započelo ili ima izgleda da će započeti }\end{array}$ & $\begin{array}{l}\text { Natrulo ili nepravilno. Nema indicija } \\
\text { da će čišćenje od grana započeti }\end{array}$ \\
\hline Rašlja (račva) & $\mathrm{Ne}$ & Da \\
\hline Zakrivljenost & $\mathrm{Ne}$ & Da \\
\hline Ozljede debla & $\mathrm{Ne}$ & Da, ako će to imati značaj u budućnosti \\
\hline Izlomljene i suhe grane & $\mathrm{Ne}$ u gornjem dijelu krošnje & Da, ako su u gornjem dijelu krošnje \\
\hline Imela ili vilina metla & $\mathrm{Ne}$ & Da \\
\hline Nadvišeno & $\mathrm{Ne}$ od boljih stabla & Da \\
\hline Zastarčeno & $\mathrm{Ne}$ & Svako \\
\hline Prevršeno & $\mathrm{Ne}$ & Da \\
\hline Prelomljeno & $\mathrm{Ne}$ & Svako \\
\hline Suhovrho & $\mathrm{Ne}$ & Svako \\
\hline Rak & $\mathrm{Ne}$ & Svako \\
\hline
\end{tabular}




\section{Pavlič Janez \\ 1.5 UZGOJNO-TEHNIČKA KLASIFIKACIJA STABALA BIJELOG I CRNOG BORA PRSNOG PREČNIKA $50 \mathrm{~cm}$ I VIŠE S KOROM}

\begin{tabular}{|c|c|c|}
\hline $\begin{array}{l}\text { Elementi koji se } \\
\text { ocjenjuju }\end{array}$ & Prva kiasa & Treća klasa \\
\hline 1 & 2 & 3 \\
\hline $\begin{array}{l}\text { Zdravstveno stanje i } \\
\text { izgled stabla }\end{array}$ & Zdravo i normaino formirane & $\begin{array}{l}\text { Loše formirano, jako ozlijedeno, trulo, } \\
\text { natrulo ili bolesno }\end{array}$ \\
\hline Cetine & Zdrave i zelene & Blijede ili prorjeđene \\
\hline Nadžilje & Deformisano do $1.5 \mathrm{~m}$, nije natrulo. & Natrulo \\
\hline Deblo & 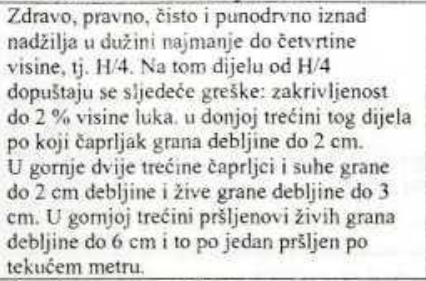 & $\begin{array}{l}\text { Svako natrulo i ono zdravo stablo iz čije se } \\
\text { donje } \mathrm{H} / 3 \text { ne može izdvojiti ni dio debla } \\
\text { dužine } 3 \mathrm{~m} \text { sa jednom od sljedećih grešaka: } \\
\text { tri grane po tekučem metru debljine do } 10 \\
\text { cm: zakrivljenost debla do } 5 \% \text { visine luka; } \\
\text { usukanost po tekućem metru do } 25 \% \\
\text { prečnika; ili istovremeno sve navedene } \\
\text { greške }\end{array}$ \\
\hline Rašlja (račva) & Dopuśtena u gornjoj $\mathrm{H} / 2$ & $\begin{array}{l}\text { Ako su predhodni uslovi takvi svrstava se u } \\
\text { III klasu bez obzira na rašlju }\end{array}$ \\
\hline Zakrivljenost & Dopustena u gornjoj $\mathrm{H} / 2$ & Neograničeno \\
\hline Ozljede debla & Dozvoljena do $10 \mathrm{~cm}$ sirine & $\begin{array}{l}\text { Za bijeli bor ako je šira od } 10 \mathrm{~cm}, \text { za crni } \\
\text { bor ako je šira od } 15 \mathrm{~cm} \text {. }\end{array}$ \\
\hline Smolareno & $\begin{array}{l}\text { Spada u ovu klasu ako je smolareno } \\
\text { francuski na živo. Drugo ne. }\end{array}$ & Svako stablo smolareno na mrtvo \\
\hline Izlomljene i suhe grane & $\begin{array}{l}\text { Dozvoljene u gomjoj } 2 / 3 \text { krošnje s tim da } \\
\text { njihov } \\
\text { broj nije veći od } 1 / 10 \text { svih živih grana u tom } \\
\text { dijelu krošnje }\end{array}$ & Neograničeno \\
\hline Imela & $\mathrm{Ne}$ & $\begin{array}{l}\text { Da , ako je zahvatila - javila se na više od } \\
10 \% \text { grana }\end{array}$ \\
\hline Nadvišeno & $\mathrm{Ne}$ & Da ako ima i druge nedostatke \\
\hline Zastarčeno & $\mathrm{Ne}$ & Da ako ima i druge nedostatke \\
\hline Prevršeno & $\mathrm{Ne}$ & $\begin{array}{l}\text { Da, ako je prevršeno više od } 1 / 5 \text { dužine } \\
\text { krošnje ili } \\
\text { više od } \mathrm{H} / 10\end{array}$ \\
\hline Prelomljeno & $\mathrm{Ne}$ & Svako \\
\hline Suhovrho & $\mathrm{Ne}$ & Više od $\mathrm{i} / 5$ dužine krošnje ili više od $\mathrm{H} / 10$ \\
\hline Rak & $\mathrm{Ne}$ & $\mathrm{Da}$, ako je bolesno \\
\hline
\end{tabular}

\subsection{UZGOJNO-TEHNIČKA KLASIFIKACIJA STABALA BIJELOG I CRNOG BORA PRSNOG PREČNIKA 30-50 cm S KOROM}

\begin{tabular}{|c|c|c|}
\hline $\begin{array}{l}\text { Elementi koji se } \\
\text { ocjenjuju }\end{array}$ & Prva klasa & Treća klasa \\
\hline 1 & 2 & 3 \\
\hline $\begin{array}{l}\text { Zdravstveno stanje i } \\
\text { izgled stabla }\end{array}$ & Zdravo i normalno formirano & $\begin{array}{l}\text { Loše a zdravo, jako oboljeło ili } \\
\text { ozlijedeno, natrulo ili trulo }\end{array}$ \\
\hline Cetine & Zdrave i zelene & Blijede ili prorjedene \\
\hline Nadžilje & $\begin{array}{l}\text { Dopušteno deformisano do } 1,5 \mathrm{~m} \text {, } \\
\text { Natrulo ili trulo nije dopušteno }\end{array}$ & Natrulo ili trulo \\
\hline Deblo & Kao za stablo $50 \mathrm{~cm}$ i više. & Kao za stablo $50 \mathrm{~cm}$ i više. \\
\hline Rašlja (račva) & $\begin{array}{l}\text { Dopuštena u gornjoj } \mathrm{H} / 3 \text { (u gornjoj trećini } \\
\text { visine) }\end{array}$ & Neograničeno \\
\hline Zakrivljenost & U gornjoj trećini visine stabla dopuštena & Neograničeno \\
\hline Ozljede debla & Dozvoljena do širine $10 \mathrm{~cm}$ & $\begin{array}{l}\text { Bijeli bor ako je šira od } 10 \mathrm{~cm} \\
\text { Crmi bor ako je šira od } 15 \mathrm{~cm}\end{array}$ \\
\hline Smolareno & $\mathrm{Ne}$ & Na mrtvo - svako stablo \\
\hline Izlomljene i suhe grane & $\begin{array}{l}\text { Dopušteno u gornje } 2 / 3 \text { krošnje, ali ne više } \\
\text { od } 1 / 10 \text { svih grana u tom dijelu krošnje }\end{array}$ & Neograničeno \\
\hline Nadvišeno & $\mathrm{Ne}$ & Da, ako ima i druge mane \\
\hline Zastarčeno & $\mathrm{Ne}$ & $\mathrm{Da}$, ako ima i druge mane \\
\hline Prevršeno & $\mathrm{Ne}$ & $\begin{array}{l}\text { Više od } 1 / 10 \text { dužine krošnje ili više od } \\
\mathrm{H} / 20\end{array}$ \\
\hline Prelomljeno & $\mathrm{Ne}$ & Svako \\
\hline Suhovrho & $\mathrm{Ne}$ & Svako \\
\hline Rak i imela & Kao kod klase iznad $50 \mathrm{~cm}$ & Kao kod klase iznad $50 \mathrm{~cm}$ \\
\hline
\end{tabular}


Methodology of measurement and registration of data in even-aged stands of spruce ...

\subsection{UZGOJNO-TEHNIČKA KLASIFIKACIJA STABALA BIJELOG I CRNOG BORA PRSNOG PREČNIKA 10-30 cm S KOROM}

\begin{tabular}{|c|c|c|}
\hline $\begin{array}{c}\text { Elementi koji se } \\
\text { ocjenjuju }\end{array}$ & Prva klasa & Treća klasa \\
\hline 1 & 2 & 3 \\
\hline $\begin{array}{l}\text { Zdravstveno stanje i } \\
\text { izgled stabla }\end{array}$ & Zdravo i normalno formirano & Loše, jako ozlijeđeno, natrulo trulo ili bolesno \\
\hline Cetine & Zdrave i zelene & Blijede ili prorjedene \\
\hline Nadžilie & Bez deformaciia & Deformisano više od $1 \mathrm{~m}$ \\
\hline Debio & $\begin{array}{l}\text { Zdravo, pravno i punodrvno u cijeloj } \\
\text { visini stabla. Ako je čišcenje od grana } \\
\text { takvo da u donjoj H/4 nema živih } \\
\text { grana i ako postoje izgledi da će se } \\
\text { nastaviti taj proces s obzirom na } \\
\text { polożaj stabla }\end{array}$ & $\begin{array}{l}\text { Natruło, oboljelo, trulo i ono zdravo koje ime } \\
\text { jedan od sljedećih nedostataka: čišćenje u donjoj } \\
\mathrm{H} / 4 \text { nije započelo i nema izgleda da će se } \\
\text { nastaviti tj. započeti u narednih } 10 \text { godina. } \\
\text { Usukanost po tekućem metru veću od } 10 \% \text { D. } \\
\text { Jednostranu zakrivljenost od } 2 \% \text { visine luka ili } \\
\text { više. Višestruko zakrivljeno. }\end{array}$ \\
\hline Rašlja (račva) & $\mathrm{Ne}$ & Neograničeno \\
\hline Zakrivljenost & $\mathrm{Ne}$ & Neograničeno \\
\hline Ozliede debla & $\mathrm{Ne}$ & Svako ako će ozljeda imati praktičan značaj \\
\hline Smolareno & $\mathrm{Ne}$ & Svako namrtvo smolareno \\
\hline Izlomijene i suhe grane & $\mathrm{Ne}$ & Neograničeno \\
\hline Imela ili vilina metla & $\mathrm{Ne}$ & Da, ako se javila na više od $10 \%$ grana \\
\hline Nadvišeno & Ne od boljih stabla & Svako ako ima i druge mane \\
\hline Zastarčeno & $\mathrm{Ne}$ & Svako \\
\hline Prevršeno & $\mathrm{Ne}$ & $\mathrm{Da}$, ako ima i druge mane \\
\hline Prelomljeno & $\mathrm{Ne}$ & Svako \\
\hline Suhovrho & $\mathrm{Ne}$ & Svako \\
\hline Rak & $\mathrm{Ne}$ & Svako, ako je bolesno \\
\hline
\end{tabular}

\subsection{LZGOJNO TEHNIČKA KLASIFIKACIJA STABALA BIJELOG I CRNOG BORA TANJIH OD 10 crn S KOROM}

\begin{tabular}{|c|c|c|}
\hline $\begin{array}{l}\text { Elementi koji se } \\
\text { ocjenjuju }\end{array}$ & Prva klasa & Treća klasa \\
\hline 1 & 2 & 3 \\
\hline $\begin{array}{l}\text { Zdravstveno stanje i } \\
\text { izgled stabla }\end{array}$ & Zdravo i normalno formitano & $\begin{array}{l}\text { Loše a zdravo, ozlijedeno, natrulo, trulo ili } \\
\text { bolesno }\end{array}$ \\
\hline Cetine & Zdrave i zelene & Blijede ili prorjedene \\
\hline Nadžilje & Bez deformacija & Natrulo ili trulo \\
\hline Deblo & $\begin{array}{l}\text { Zdravo, pravno i punodrvno u cijeloj } \\
\text { visini. Cišćenje od grana je započelo i ima } \\
\text { izgleda da će se nastaviti }\end{array}$ & $\begin{array}{l}\text { Natrulo, trulo ili nepravilno. Nema indicija da } \\
\text { će čšćcnje od grana započeti u narednoj } \\
\text { deceniji }\end{array}$ \\
\hline Rašlja (rač́va) & $\mathrm{Ne}$ & $\mathrm{Da}$ \\
\hline Zakrivljenost & $\mathrm{Ne}$ & 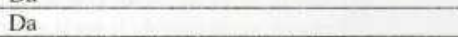 \\
\hline Ozliede debla & $\mathrm{Ne}$ & Da, ako će to imati značaj u budućnosti \\
\hline Smolareno & $\mathrm{Ne}$ & Svako \\
\hline izlomijene i suhe grane & Ne u gornjem dijelu krošnje & Da, ako su u gornjem dijelu krošnje \\
\hline Imela & $\mathrm{Ne}$ & $\mathrm{Da}$ \\
\hline Nadvišeno & Ne od boljih stabla & Svako ako ima i drugih mana \\
\hline Zastarčeno & $\mathrm{Ne}$ & Svako \\
\hline Prevršeno & $\mathrm{Ne}$ & Svako \\
\hline Prelomljeno & $\mathrm{Ne}$ & Svako \\
\hline Suhovrho & $\mathrm{Ne}$ & Svako \\
\hline Rak & $\mathrm{Ne}$ & Svako \\
\hline
\end{tabular}




\section{TEHNIČKA KLASIFIKACIJA STABALA SMRČE, BJELOG I CRNOG BORA PREMA MATIĆ V. et al., 1971)}

Svrha tehničke klasifikacije stabala je da prikaže sastav sastojina u pogledu tehničke upotrebljivosti stabala za izradu pojedinih šumskih sortimenata. Ta kasifikacija ima, prema Matić-u, četiri kvalitetne klase kada se radi o stablima prsnog prečnika 30 i više $\mathrm{cm}$ s korom. Za stabla tanja od $30 \mathrm{~cm}$ Matić je formirao samo tri klase: I, III i IV.

Pri prikupljanju podataka za ovaj naučno-istraživački zadatak primjenit će se za stabla svih debljina četiri tehničke kvalitetne klase: 1., 2., 3., i 4.

Kriteriji za tehničku klasifikaciju stabala razrađeni su posebno za smrču i posebno za bijeli i crni bor i to odvojeno za stabla prsnog prečnika 30 i više cm i za stabla tanja od $30 \mathrm{~cm}$.

\subsection{TEHNIČKA KLASIFIKACIJA ZA STABLA SMRČE, BIJELOG I CRNOG BORA PRSNOG PREČNIKA $30 \mathrm{~cm}$ I VIŠE S KOROM.}

\begin{tabular}{|c|c|c|}
\hline $\begin{array}{c}\text { Tehnička } \\
\text { klasa }\end{array}$ & Smrča & Bijeli i crni bor \\
\hline 1. & $\begin{array}{l}\text { Iz donje polovine visine stabla može se iz cijela } \\
\text { ili iz više komada dobiti dio zdravog,pravog } \\
\text { i punodrvnog debla dužine } \mathrm{H} / 3 \text { iliviše. Pojedini } \\
\text { komad debla ne smije biti krači od } 4 \mathrm{~m} \text {. Na } \\
\text { dijelu debla minimalne dužine } \mathrm{H} / 3 \text { tolerišu se } \\
\text { istovremeno: u donjoj trećini po koji suhi ča- } \\
\text { prljak; u gornje } 2 / 3 \text { suhe grane do } 2 \mathrm{~cm} \text { debljine } \\
\text { i žive grane do } 3 \mathrm{~cm} \text { debljine neograničeno; u } \\
\text { gornjoj trećini najviše dvije žive grane po } \\
\text { dužnom metru debljine do } 6 \mathrm{~cm} \text { ili po dva } \\
\text { pršljena takvih grana. }\end{array}$ & $\begin{array}{l}\text { Iz donje trećine visine stabla može se iz cijela ili } \\
\text { iz više komada dobiti dio pravnog i punodrvnog } \\
\text { debla minimalne dužine do } \mathrm{H} / 4 \text {. Pojedini komadi } \\
\text { ne smiju biti kraći od } 4 \mathrm{~m} \text {. Na minimalnoj dužini } \\
\text { debla od } \mathrm{H} / 4 \text { mogu istovremeno biti sljedeće } \\
\text { greške: zakrivljenost do } 2 \% \text { visine luka: u donjoj } \\
\text { trećini po koji čaprljak debljine do } 2 \mathrm{~cm} \text {; u gornje } \\
2 / 3 \text { čaprljci i suhe grane do } 3 \mathrm{~cm} \text { debljine } \\
\text { neograničeno; u gornjoj trećini žive grane } \\
\text { debljine do } 6 \mathrm{~cm} \text { i to jedna po tekućem metru ili } \\
\text { jedan pršljen takvih grana po tekućem metru. }\end{array}$ \\
\hline 2. & $\begin{array}{l}\text { Iz donje polovine visine stabla može se izdvojiti } \\
\text { jedan komad debla dužine bar } 3 \mathrm{~m} \text {. On smije da } \\
\text { ima samo jednu od sljedećih grešaka: } \\
\text { najviše tri grane po dužnom metru debljine } 10 \\
\mathrm{~cm} \text {; zakrivljenost do } 5 \% \text { visine luka; usukanost } \\
\text { po dužnom metru do } 25 \% \text { od prečnika na toj } \\
\text { dužini }\end{array}$ & $\begin{array}{l}\text { Iz donje trećine visine stabla može se izdvojiti iz } \\
\text { cijela (u jednom komadu) dio debla dužine bar } \\
3 \mathrm{~m} \text {. On smije da ima samo jednu od sljedećih } \\
\text { grešaka: najviše tri grane po dužnom metru } \\
\text { debele } 10 \mathrm{~cm} \text {; zakrivljenost do } 5 \% \text { visine luka; } \\
\text { usukanost po dužnom metru do } 25 \% \text { prečnika u } \\
\text { sredini tog metra. }\end{array}$ \\
\hline 3. & $\begin{array}{l}\text { Nismo sigurni da se iz donje polovine visine } \\
\text { stabla može da izradi komad debla dužine bar } 3 \\
\text { m (jer ne znamo da li greška zatvara) i to onog } \\
\text { kvaliteta koji se traži za drugu tehničku klasu. }\end{array}$ & $\begin{array}{l}\text { Nismo sigurni da se iz donje trećine stabla može } \\
\text { dobiti dio debla dužine bar } 3 \mathrm{~m} \text { onog kvaliteta koji } \\
\text { se traži za drugu tehničku klasu (jer greška ne } \\
\text { zatvara) }\end{array}$ \\
\hline 4. & $\begin{array}{l}\text { Sigurni smo da se iz donje polovine stabla ne } \\
\text { može izdvojiti dio debla dužine bar } 3 \mathrm{~m} \text { onog } \\
\text { kvaliteta koii se traži za } 11 \text { tehničku klasu. }\end{array}$ & $\begin{array}{l}\text { Sigurni smo da se iz donje trećine visine stabla ne } \\
\text { može izraditi trupac dužine } 3 \mathrm{~m} \text { onog kvaliteta } \\
\text { koii se traži za II tehničku klasu }\end{array}$ \\
\hline
\end{tabular}

Iz opisanih kriterijuma za tehničku klasifikaciju stabala prsnog prečnika $30 \mathrm{i}$ više cm može se vidjeti da se uslovi za drugu, treću i četvrtu klasu razlikuju između smrče i bijelog i crnog bora samo po dužini iz koje se može izraditi trupac dužine bar $3 \mathrm{~m}$. Kod smrče on se mora izraditi iz donje polovine visine, a kod borova iz donje trećine visine stabala.

Kada se radi o prvoj klasi razlika je između ovih vrsta drveća u tome da se iz stabla smrče mora izraditi trupac bar dužine koja će biti jednaka trećini visine stabla, a kod borova ta dužina trupca treba da bude dugačka koliko iznosi četvrtina visine stabla. Za smrču ona mora biti izrađena iz donje polovine visine, a kod borova iz donje trećine visine stabla. 
Methodology of measurement and registration of data in even-aged stands of spruce ...

\subsection{TEHNIČKA KLASIFIKACIJA STABALA SMRĆE, BIJELOG I CRNOG BORA PRSNOG PREČNIKA ISPOD $30 \mathrm{~cm} S$ KOROM}

U prvu tehničku kvalitetnu klasu svrstavaju se sva stabla prve uzgo-

jno-tehničke klase i uz njih i ona stabla druge i treće uzgojno tehničke klase iz čije se donje $2 / 3$

visine stabla mogu. izrezivanjem samo jednog dijela debla dužine do Im, dobiti dva pravna i punodrvna dijela debla sa ukupnom dužinom od najmanje $\mathrm{H} / 2$ ili većom.

$\mathrm{U}$ drugu tehničku kvalitetnu klasu svrstavaju se ona stabla II i III uzgojno-tehničke klase iz čije se donje 2/3 visine stabla mogu, izrezivanjem dva dijela debla s greškama, dobiti pravne i punodrvne oblice s ukupnpom dužinom od $\mathrm{H} / 2$ ih većom.

U treću tehničku klasu svrstavaju se ona stabla II i III uzgojno-tehničke klase iz čije se donje $2 / 3$ visine stabla može izdvojiti komad pravnog i punodrvnog debla iz cijela (u jednom komadu), dužini od $3 \mathrm{~m}$.

$\mathrm{U}$ četvrtu tehničku kvalitetnu klasu svrstavaju se stabla ako se iz donje $2 / 3$ visine stabla ne može izdvojiti iz cijela (u jednom komadu) dio pravnog i punodrvnog debla dužine $3 \mathrm{~m}$.

Za sve tri vrste drveća kriteriji za stabla tanja od $30 \mathrm{~cm}$ su isti.

Podaci o procjenjenoj uzgojno-tehničkoj i tehničkoj klasi stabla upisuju se u kolone 12 i 13 obrasca 3, i to arapskim brojevima.

Pri upisu tih podataka mora se imati na umu veza koja postoji između uzgojno-tehničke i tehničke klasifikacije, tj. da:

- $\quad$ stablo prve uzgojno-tehničke klase mora biti svrstano u prvu tehničku klasu,

- $\quad$ stablo druge uzgojno-tehničke klase može biti svrstano samo u prvu ih drugu klasu tehničke klasifikacije,

- $\quad$ se stablo treće uzgojno-tehničke klase svrstava u onu klasu tehničke klasifikacije čije uslove za deblo ispunjava. Na primjer, suho stablo (sušika) svrstava se obavezno u treću uzgojnotehničku klasu, a može imati prvu tehničku klasu ako nije trulo i ako ima deblo onog kvaliteta i dužine koji je predviđen za tu klasu. 
Pavlič Janez

\section{IUFRO (OKSFORDSKA) KLASIFIKACIJA STABALA}

Prema Pintarić-u (1969) IUFRO klasifikacijom (ili kategorizacijom) ocjenjuje se: položaj stabla u sastojim, vitalitet stabala, tendencija razvoja stabla, uzgojna uloga stabla u sastojini, kvalitet debla, dužina krošnje i zdravstveno stanje stabla. Pri klasifikaciji koriste se šifre iskazane brojevima.

1. Položaj stablau sastojini određuje se na osnovu gornje sastojinske visine. Pod tom visinom podrazumjeva se prosječna visina $20 \%$ najviših stabala - u ovom slučaju one vrste drveća koja se smatra glavnom. Ta visina se lako može da procjeni i izračuna.

Položaj stabala u sastojini procjenjuje se za svako stablo koje podliježe premjeru.

Šifra 100: stablo gornje etaže, čija je visina veća od $2 / 3$ gornje sastojinske visine,

Šifra 200; stablo srednje etaže, čija se visina nalazi između 1/3 i 2/3 gornje sastojinske visine.

Šifra 300: stablo donje etaže, čija je visina manja od $1 / 3$ gornje sastojinske visine.

U kolonu br. 14 obrasca 3 upisuje se umjesto 100, 200, 300 samo 1, 2 ili 3, tj. početni brojevi stotica. Ako je upisan br. 1 znači da to stablo pripada gornjoj etaži. Ocjena pripadnosti etaži vrši se na bazi visine stabla.

2. Vitalnost ili vitalitet stabla procjenjuje se na osnovu sposobnosti reagovanja stabla na uzgojne zahvate.

Šifra 10: stabla jakog vitaliteta. Krošnja je ispunjena asimilacionim organima koji po svojoj brojnosti ukazuju da se stablo nalazi u optimalnim uslovima rasta. Takva jedinka sposobna je da snažno reaguje ako joj se stvore povoljni uslovi za rast;

Šifra 20: stablo je normalnog vitaliteta. Asimilacioni organi su normalne boje i gustine te se i stablo razvija normalno. Na promjenjene uslove stablo reaguje normalno;

Šifra 30: stablo slabog vitaliteta. Krošnja sa asimilacionim organima nema normalan izgled. To se ogleda u neprirodnoj boji, malobrojnosti i veličini asimilacionih organa. Jedinka nije sposobna da reaguje ili će slabo reagovati na uzgojne zahvate.

Podaci o vitalitetu stabla upisuju se u kolonu br. 15 obrasca 3, tako što se upisaju početni brojevi odgovarajuće desetice, tj. 1, 2 ili 3.

3. Tendencija razvoja stabla određuje se na osnovu brzine rastenja - priraščivanja u odnosu na susjedno stablo.

Šifra 1: stablo sa naprednom tendencijom rasta u visinu. Stablo raste brže u visinu od susjednog koje je iste ili približno iste starosti;

Šifra 2: stablo sa pratećom tendecijom razvoja u visini. Raste u visinu istom brzinom kao susjedno stablo iste starosti; 
Methodology of measurement and registration of data in even-aged stands of spruce ...

Šifra 3: stablo zaostaje u rastu. U odnosu na susjedno stablo iste ili približno iste starosti zaostaje u rastu u visini.

Podatak o tendenciji razvoja stabla upisuje se cifrom 1, 2 ili 3, u kolonu br.16 obrasca 3.

4. Uzgojna uloga stabla u sastojini ocjenjuje se na osnovu njegovog značaja za buduću proizvodnju.

Šifra 400: odabrana stabla. Tu spadaju one jedinke na kojima, prema sadašnjem izgledu, leži budućnost. To je stablo kome se pri narednim zahvatima mora posvetiti puna pažnja i kojima treba pružiti pomoć. U ovu grupu spadaju najvrednija stabla koja se nalaze isključivo u gornjoj etaži;

Šifra 500: korisno stablo. To je ono stablo koje je u funkciji pomaganja odabranog stabla (čišćenje od grana odabranog stabla, održavanje plodnosti tla);

Šifra 600: štetno stablo. Ono u posmatranom momentu najviše šteti odabranom stablu, bez obzira da li je to štetno stablo dobro ili loše po kvalitetu. U datom momentu to se stablo mora ukloniti iz sastojine (doznačiti).

Podatak o uzgojnoj ulozi stabla u sastojini upisuje se u koloni 17 obrasca 3, i to početnim brojem stotica: 4, 5 ili 6 . Ako je upisan br. 6 znači daje ocjenjeno daje to stablo štetno.

5. Kvalitet debla procjenjuje se na osnovu potencijala stabla za proizvodnju određenih sortimenata. Predviđene su sljedeće kategorije:

Šifra 40: kvalitet debla je odličan. Stablo će u doba korištenja dati najmanje $50 \%$ drvene mase visokog kvaliteta, prve klase;

Šifra 50: kvalitet stabla normalan. Stablo će u doba sječe dati najmanje $50 \%$ drvne mase prosječnog kvaliteta (II klasa trupaca za rezanje),

Šifra 60: kvalitet stabla loš. Stablo će u doba korištenja dati dvmu masu manje vrijednih sortimenata (cijepano drvo).

Ocjena kvaliteta stabla vrši se na bazi donje trećine visine stabla, jer ona sadrži oko $50 \%$ drvne mase krupnog drveta stabla.

Podatak o kvalitetu stabla upisuje se u obrazac 3 u kolonu br. 18, prvom cifrom desetice: 4, 5 ili 6.6

6. Dužina krošnje ocjenjuje se u odnosu na visinu stabla. U tu svhu može da posluži i podatak o dužini čistog debla koji se mjeri prilikom mjerenja visine stabla.

Šifra 4: stablo ima dugu krošnju. Krošnja je veća od $1 / 2$ visine stabla;

Šifra 5: stablo ima srednje dugu krošnju. Dužina krošnje je manja od 1/2 visine stabla, a duža od $1 / 4$ visine stabla;

Šifra 6: stablo kratke krošnje. Krošnja je kraća od 1/4 visine stabla.

Podatak o dužini krošnje upisuje se jednom od navedenih cifara u kolonu br.19 obrasca 3. 
7.Zdravstveno stanje stabla ocjenjuje se po vanjskim znacima.

Šifra 7: stablo je potpuno zdravo. Nema znakova oboljenja ili oštećenja;

Šifra 8: zdravstveno stanje je sumnjivo. Znaci oboljenja nisu posebno vidljivi, ali se na osnovu izgleda stabla sumnja daje ono zdravo;

Šifra 9: bolesno stablo. Na stablu su uočljivi znaci oboljenja (trulež i dr.)

Bolesno stablo može biti dobrog vitaliteta. Posebnu pažnju treba posvetiti zdravstvenom stanju vrata korjena, krošnji i deblu.

Podatak o zravstvenom stanju stabla upisuje se u manual jednom od navedenih šifri u kolonu br. 20 obrasca 3.

Ako se u kolonama 14-20 obrasca 3 nalaze upisani brojevi 122/445/7 znači da je to stablo gornje etaže, normalnog vitaliteta, prateće tedencije razvoja, da je odabrano stablo, odličnog kvaliteta debla, ima srednju dugu krošnju i da je potpuno zdravo.

Podaci o procjenjenim osobinama stabla prema IUFRO klasifikaciji upisuju se u kolone 14-20 obrasca 3 arapskim brojevima.

Pri ocjeni pojedinih osobina stabla po IUFRO klasifikaciji treba voditi računa da one budu u skladu sa uzgojno-tehničkom i tehničkom klasom stabala. Ako je, na primjer ocjenjeno da stablo pripada prvoj uzgojno-tehničkoj klasi, tada po IUFRO klasifikaciji mora dobiti najbolju ocjenu za položaj, kvalitet debla i zdravstveno stanje. 
OBRAZAC 1.

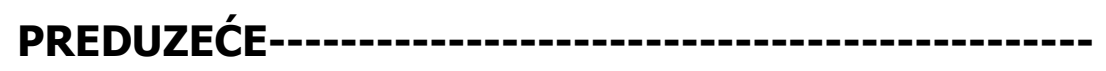

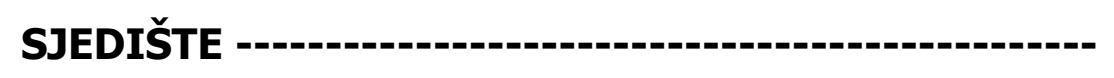

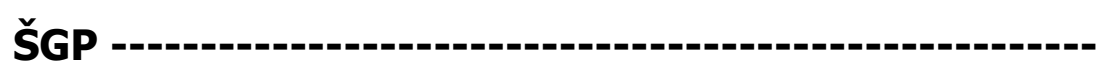

OGLEDNA PLOHA

BR.--------------

Mjerio:

Datum mjerenja:-

(čitko ime i prezime) 


\section{OGLEDNA PLOHA BR.}

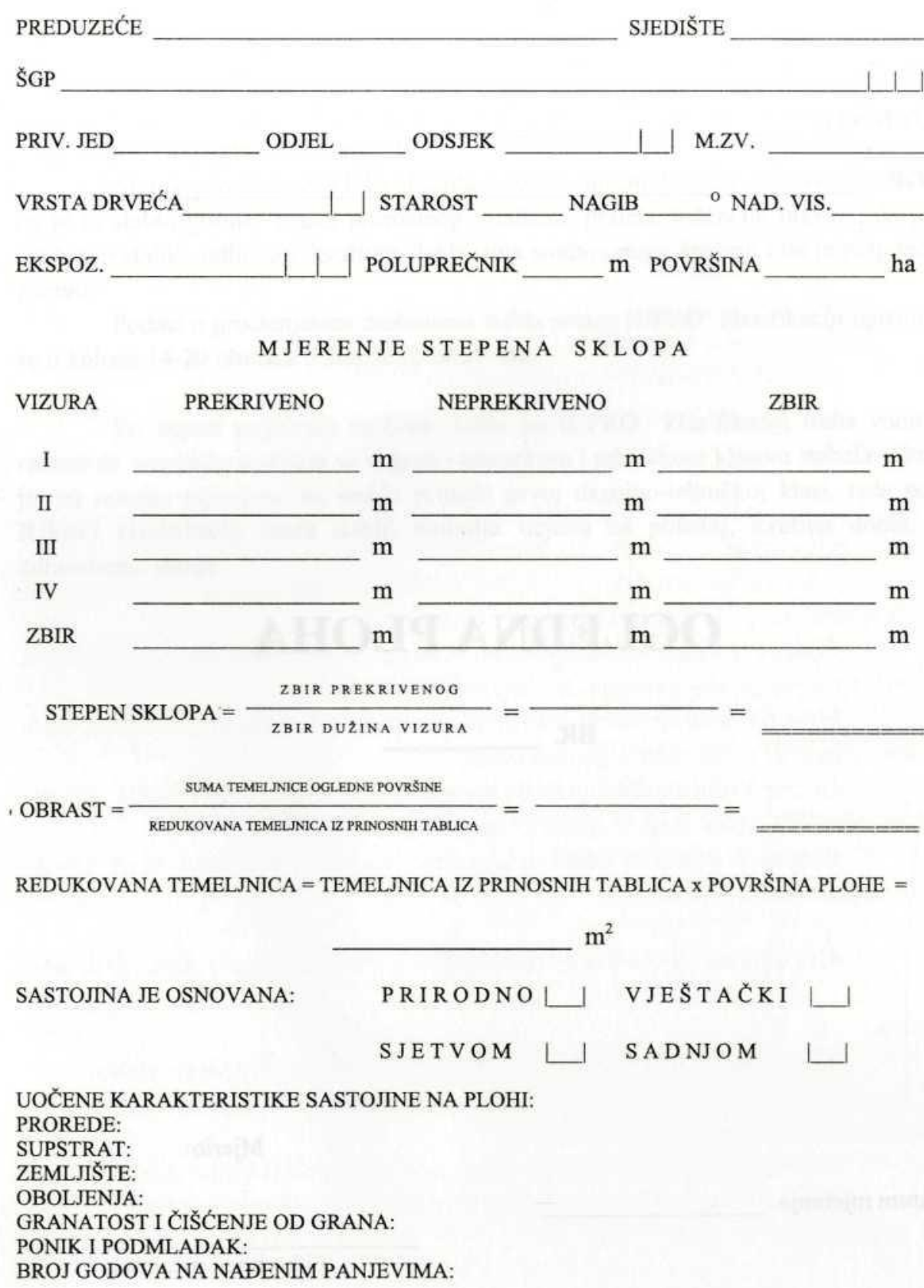




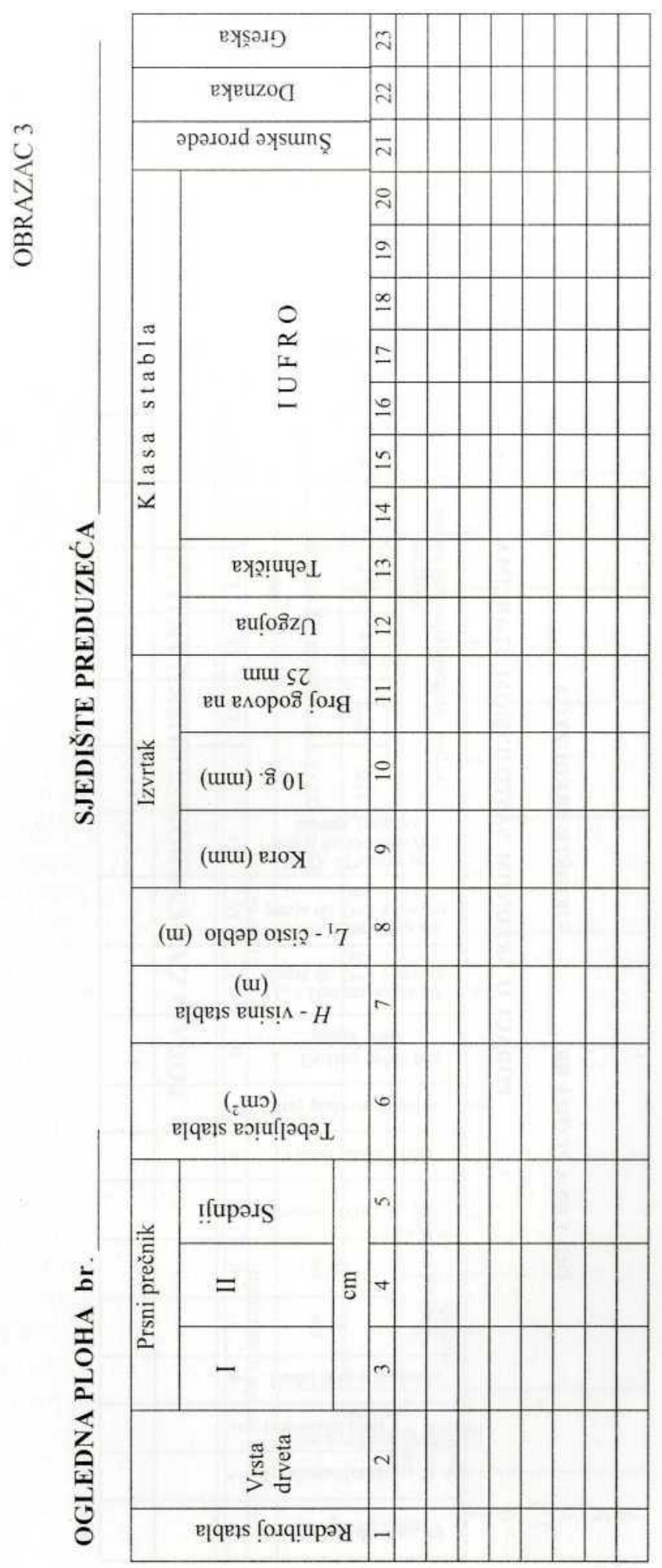




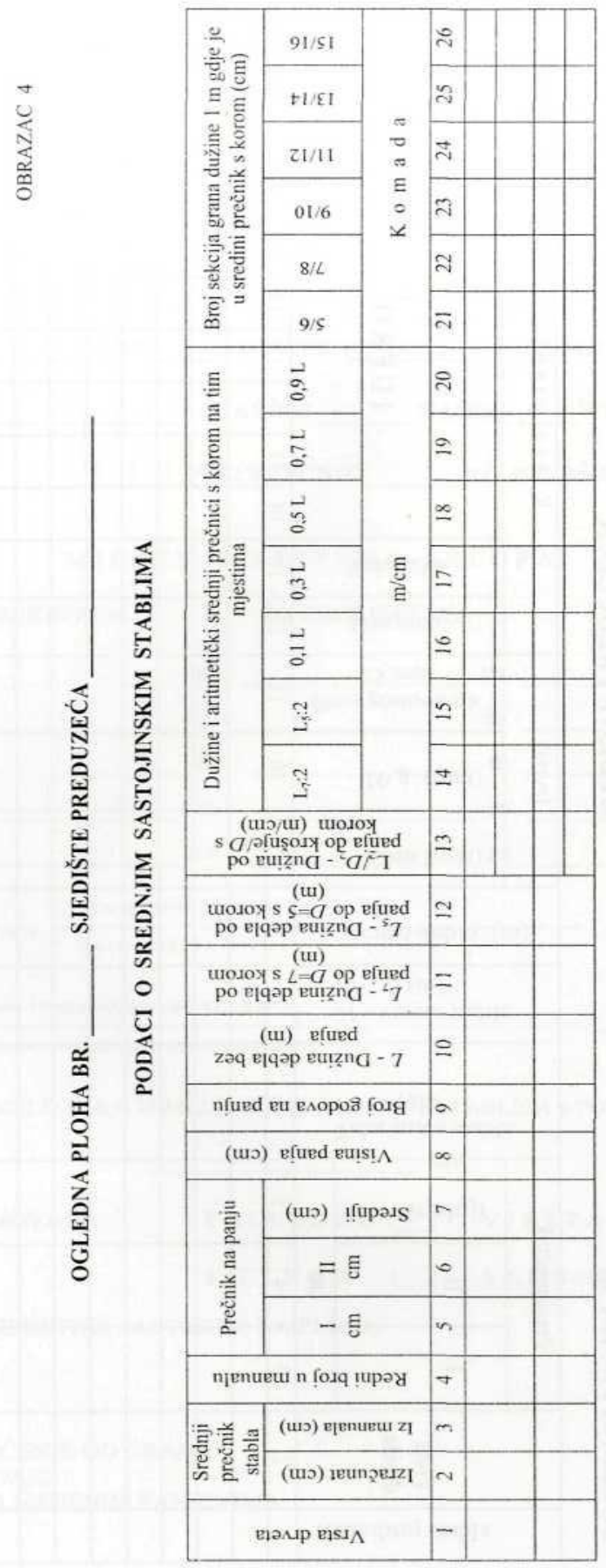


感

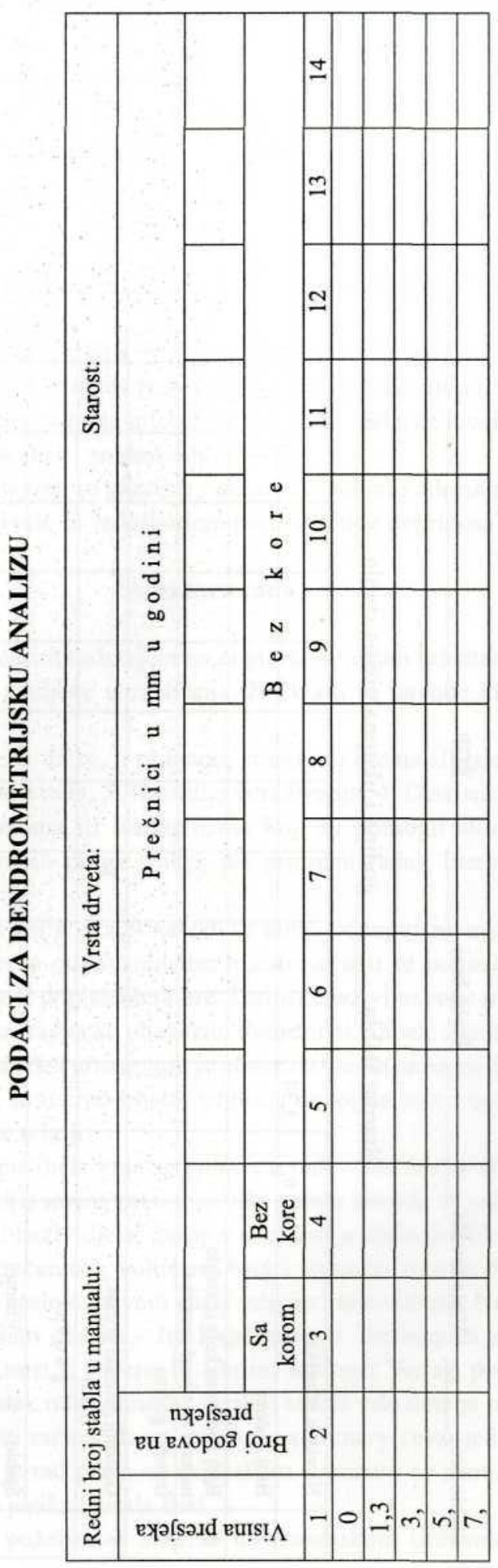




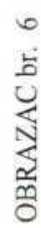

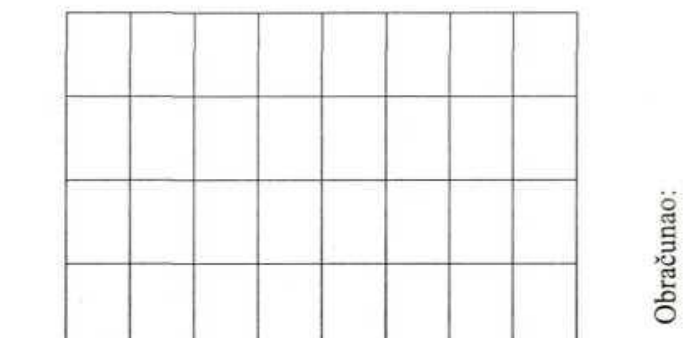

:

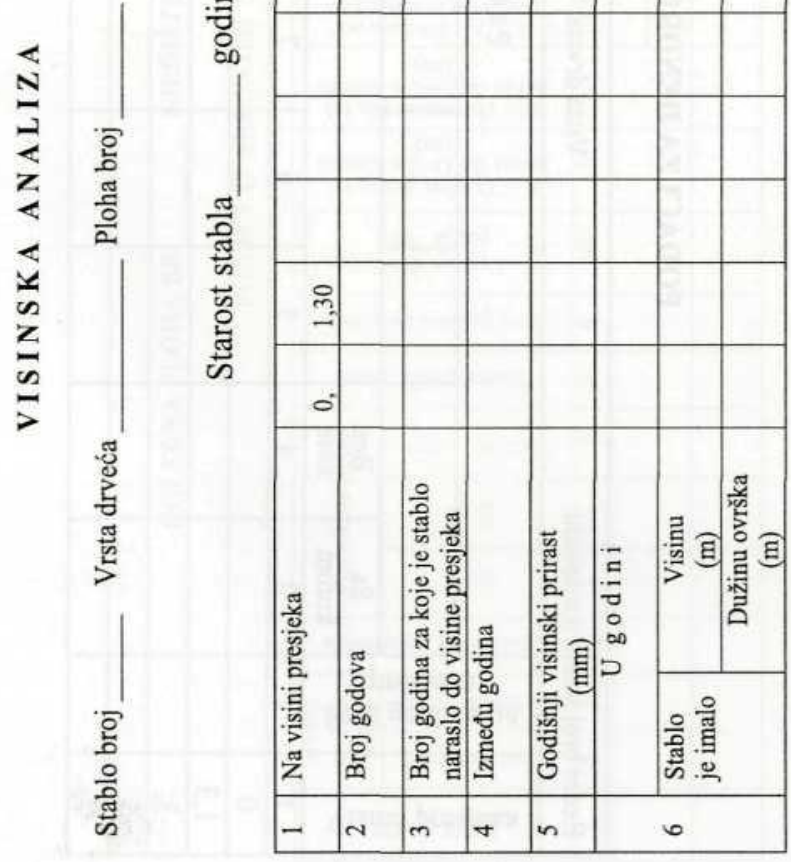

$\mid$ 
